\title{
RENEWABLE ENERGY USE IN RASPBERRY PRODUCTION ${ }^{1}$
}

\author{
Jonel Subič², Nataša Kljajič3, Marko Jeločnik ${ }^{4}$
}

\begin{abstract}
Paper's focus is on the economic effects of introducing energy from renewable sources (solar energy) in the raspberry production (mainly for irrigation). Main goal is to assess economic effectiveness of investment in establishing and exploiting raspberry plantation, as well as implementation of required equipment and mechanization, from the point of two investment scenarios. First scenario considers conventional way of raspberry production, compared to raspberry production under mobile solar robotized electric generator. Methodologically, the analysis implies application of a set of methods for dynamic evaluation of investment and methods for evaluation of investments under uncertainty (the net present value, the internal rate of return, the payback period and the break-even point). The result of conducted assessment shows that, apart from ecological benefit, there is high economic justification of investment into device used for transfer of renewable into electric energy in raspberry production.
\end{abstract}

Key words: raspberry production, investment estimation, renewable energy.

JEL: Q120, Q420

\section{Introduction}

Orchards are on area of 163,310 ha, with a share of around $4.7 \%$ within the totally used agricultural area, or around $6.2 \%$ of arable land at the territory of Republic of Serbia (Keserović et al., 2014). In fruit production, the highest economic importance has production

1 Paper is a part of project research III 46006 - Sustainable agriculture and rural development in function of Republic of Serbia strategic goals achievement within the Danube region, financed by the Ministry of Education, Science and Technological Development of the Republic of Serbia.

2 Jonel Subić Ph.D., Associate Professor, Senior Research Fellow, Institute of Agricultural Economics, Volgina Street no. 15, 11060 Belgrade, Republic of Serbia, Phone: +381 116972 858, E-mail: jonel_s@iep.bg.ac.rs

3 Nataša Kjajić Ph.D., Research Associate, Institute of Agricultural Economics, Volgina Street no. 15, 11060 Belgrade, Republic of Serbia, Phone: +381 116972 858, E-mail: natasak@iep.bg.ac.rs

4 Marko Jeločnik, M.A., Professional Associate, Institute of Agricultural Economics, Volgina Street no. 15, 11060 Belgrade, Republic of Serbia, Phone: +381 116972 858, E-mail: marko_j@iep.bg.ac.rs

EP 2017 (64) 2 (821-843) 
of berry fruits, especially raspberry. Raspberries have excellent market potential, because of outstanding flavor and juiciness, high nutritive and technological value, which all makes it a very appreciated and demanded fruit (Kljajić, 2016).

Use of this, primarily dessert fruit is mainly as fresh or frozen in consumption, or as a raw material in the food industry (production of juices, compotes, alcoholic beverages, confectionery, ice creams, jams, etc.). Its advantage lies in the short period from planting until the time of full yield, season of appearance at the market, the lower level of production risk in relation to adverse climatic factors (hail, late spring frost or wind, etc.). It is adaptable to different climatic and soil conditions. It can be grown in the altitude up to the 1,000 meters above sea level (Blagojević, Božić, 2012).

In the period of 2012-2016, in average the raspberry was produced on the area of almost 11.5 thousand hectares, with average yield of around $5.8 \mathrm{t} /$ ha with the total annual production of about 65.7 thousand tons (Table 1.). It is dominantly produced (over the $95 \%$ of entire areas under the raspberry) on the territory of Central Serbia (Kljajić et al., 2013).

Table 1. Raspberry production in the Republic of Serbia (period 2012-2016)

\begin{tabular}{|c|c|c|c|}
\hline \multirow{2}{*}{ Year/Element } & \multicolumn{3}{|c|}{ Serbia } \\
\cline { 2 - 4 } & Production area (ha) & Total production (t) & Yield (t/ha) \\
\hline 2012. & 11,996 & 70,320 & 5.9 \\
\hline 2013. & 12,025 & 68,458 & 5.7 \\
\hline 2014. & 11,041 & 61,715 & 5.6 \\
\hline 2015. & 11,041 & 66,176 & 6.0 \\
\hline 2016. & 11,041 & 61,875 & 5.6 \\
\hline Average & 11,429 & 65,709 & 5.8 \\
\hline
\end{tabular}

Source: RZS, 2017.

According to FAO, during the last several years Serbia was positioned among the leading global raspberry producers (Table 2.). Almost $90 \%$ of raspberry production is processed as frozen in cold house plants, while only $10 \%$ is marketed as fresh. Almost $95 \%$ of Serbian raspberries are the North American Willamette variety (Stojanović et al., 2014), grown by more than 45.3 thousands agricultural holdings (primarily family owned), (Paraušić, Simenunović, 2016).

Table 2. Leading raspberry producers in the world (period 2012-2014)

\begin{tabular}{|l|l|r|r|r|r|r|r|}
\hline \multicolumn{2}{|c|}{ Year/Element } & \multicolumn{7}{c|}{ Country } \\
\cline { 3 - 8 } & \multicolumn{1}{|c|}{ Russia } & \multicolumn{1}{c|}{ Poland } & USA & Serbia & Mexico & Ukraine \\
\hline \multirow{2}{*}{2012.} & Production (t) & 133,000 & 127,055 & 84,300 & $\mathbf{7 0 , 3 2 0}$ & 17,009 & 30,300 \\
\cline { 2 - 8 } & Yield (t/ha) & 5.1 & 4.5 & 12.0 & $\mathbf{5 . 9}$ & 14.5 & 6.1 \\
\hline \multirow{2}{*}{2013.} & Production (t) & 143,000 & 121,040 & 83,280 & $\mathbf{6 8 , 4 5 8}$ & 30,411 & 29,510 \\
\cline { 2 - 8 } & Yield (t/ha) & 8.9 & 4.2 & 11.1 & $\mathbf{5 . 7}$ & 15.5 & 5.8 \\
\hline \multirow{2}{*}{2014.} & Production (t) & 144,000 & 125,859 & 103,510 & $\mathbf{6 1 , 7 1 5}$ & 35,627 & 30,800 \\
\cline { 2 - 8 } & Yield (t/ha) & 8.7 & 4.4 & 13.1 & $\mathbf{5 . 6}$ & 15.2 & 6.3 \\
\hline
\end{tabular}

Source: FAOSTAT, 2017. 
Raspberry is one of the most important products for Serbian export. Most of the production is exported to EU market. Previous years, as major export destinations were Germany, France, Belgium, USA, UK, Sweden, etc. (Kljajić et al., 2017).

It is usually exported as frozen (mostly in the form of IQF Rolend, groats and blocks), with stable price of around $1.5 \mathrm{EUR} / \mathrm{kg}$. Some estimations are that with export of fresh raspberry in map package - modified atmosphere packaging, it could achieve up to 2-3 times higher price, but export of fresh or high level of processed such as concentrated form is rare. Small share of fresh raspberry export is a direct cause of high level of fruit perishability (Kljajić, 2014).

In relation to production, raspberry does not tolerate moist soils, and is very sensitive to drought, since $80 \%$ of its root system lies at the depth of up to $50 \mathrm{~cm}$ in the soil complex. Good development of seedlings, high and stable yields, as well as good fruits quality will be ensured only with sufficient soil moisture throughout the entire growing season. Raspberry plantations are usually irrigated with drip system, whereby modern raspberry varieties by its yield, quality and fruit firmness have very good respond to optimal amount of water and irrigation timing (irrigation could increase yields for 2-3 times). Also, this way of irrigation has positive reflection on yield potential in next vegetation (Trajković, Milanović, 2012).

Plant has significant requirements for water that are the mostly expressed from the beginning of growing season up to the harvesting. As critical periods stage of flowering, along with the stages of fruit growing and maturation could be marked. Approximate timings for proper application of irrigation cycles in Serbian conditions are during mid-April, at the beginning of May, at the beginning of June (two weeks before the harvesting), at the end of June (in the midst of harvest) and during the mid-July (after the harvest - initiating the sprouts growing on which will be generated the fruits during the next vegetation). Each irrigation cycle should be followed by adequate soil tillage. On the other hand at the territories with lots of rainfall and without extremely high temperatures usually there are no need for irrigation up to the June (first cycle is usually performed shortly before the stage of fruits ripening, and next one at the mid of mentioned stage). Despite the importance of this agro technical measure, unfortunately a great number of raspberry plantations are not covered by irrigation systems (Veličković, 2007; Milenković et al., 2011; Nastić, 2014).

\section{Data sources and methodology}

The paper deals with the use of renewable energy sources in agricultural production, specifically fruit production. The main goal is to analyze the profitability of investment in renewable energy within the process of raspberry production. The comparative analysis of raspberry plantation in traditional production against production that includes the use of renewable energy sources (primary solar energy) is done ${ }^{5}$. For this purpose two evaluation scenarios are tested based on field (real) data (agricultural holding is located at

5 Renewable energy and agriculture could be win-win combination. Wind, solar and thermal energy and biomass can be used forever, providing agricultural producers long-lasting source of cheap energy (additional income), (UCS, 2003).

EP 2017 (64) 2 (821-843) 
the territory of Čačak city). Main difference between the observed scenarios is based on the introduction of mobile robotized solar electro generator in order to conduct irrigation process. Assessment of economic effects of investment in establishment of raspberry plantation and purchase of needed equipment and mechanization was done by the use of software application for the development of business plans in any sector of agricultural production (results of the Project: Improvement of financial knowledge and recording on agricultural holdings, funded by the Ministry of Agriculture and Environmental Protection of the Republic of Serbia) ${ }^{6}$.

The evaluation includes the use of a set of methods for dynamic evaluation of investment economic effectiveness and methods for investments assessment under uncertainty (the net present value, the internal rate of return, the payback period and the break-even point). All in paper displayed values are expressed in RSD and adjusted to the production land parcel of one hectare. All statements in the paper are adjusted to available scientific and professional literature.

\section{Research results with discussion}

Individual agricultural holding is located at the territory of Čačak city (Moravički district). For couple of decades the holding has turned to fruit growing, specifically to raspberry production. In order to improve the current production and to increase competitiveness of holding, the owner decides, after cutting down existing and already exploited plantation, to make an investment in the new plantation, which would include new technical and technological techniques and equipment, such as the use of adequate variety and drip irrigation systems. Also in order to achieve planned expansion of production, new machinery will be purchased. According to the owner affinity toward environmental protection, the purchase of a mobile robotized solar electric generator, with primary purpose in irrigation will be considered. Additionally, the high mobility of this electrical device will enable, during the periods in which raspberry is not irrigated, its use in other activities carried out at the holding.

Holding has on disposal the production parcel of 1 ha, with quadratic shape that lies on the terrain with slight slope. Soil is in good quality. The parcel is located almost one kilometer out of the holding, so there is a need for electrical infrastructure that will run the irrigation system or it will be used for some other purposes at the production parcel. Mobile solar system is changing electrical infrastructure needed so far (Jovanović et al., 2017). Close to production parcel a well would be drilled with the adequate capacity. Holding is not in VAT system.

Planned investment will be financed by combination of own and external capital. Credit will cover the financing of the irrigation system (including the water pump) and electric

6 Project was realized during the period August-December 2016. with the engagement of four partner scientific-research institutions (Institute of Agricultural Economics, Belgrade; Institute for appliance of Science in Agriculture, Belgrade; University of Belgrade, Faculty of Agriculture; and Fruit Research Institute, Čačak) and four Agricultural extension services from Jagodina, Šabac, Smederevo and Mladenovac. 
generator purchase, while own assets will be used for financing well drilling, the electrical infrastructure, purchase of mechanization, equipment and seedlings, costs of ground activities in order to prepare the land complex for establishment of raspberry plantation, as well as the value of permanent working capital (PWC). Planned modernization of the production process is turned to introduction of higher yield variety (variety Willamette that has showed good adaptability to the Serbian production conditions, allowing the intensive exploitation of raspberry plantation for 12-15 years, providing the high yields within the period of full productivity from 15 to more t/ha and without requirement for additional fruits classification after the picking), modernization of the irrigation system (drip system) and mechanization, as well as to possible introduction of renewable energy into the production process.

Raspberry production is in line with the fundamentals of integrated production (controlled application of mineral fertilizers and pesticides), where agricultural holding consistently adheres to the principles of good agricultural practices in terms of soil tillage, crop cultivation, manipulation with fruits, etc. By introduction of renewable energy ${ }^{7}$ within the production process, farm will additionally boost the component of quality and food safety, increasing selling price for the fruits.

Owner will invest in electric renewable (solar) energy generator ${ }^{8}$, only if the indicators of economic effectiveness of investment project, which includes the use of renewable energy, would not be significantly worse than indicators related to the basic investment. Therefore, further analysis will follow two investment scenarios: Scenario 1, which considers plantation establishment, purchase of necessary mechanization and equipment, well drilling, implementation of the irrigation system and required electrical infrastructure; and Scenario 2, which is additionally burdened by the purchase of a mobile robotized solar electro-generator minus the costs of electrical infrastructure to the production parcel.

Total investment will be presented in next tables (Table 3. and 4.). Specifically, it would involve financing in: a) facilities - costs of well digging and building up to the depth of 45 $\mathrm{m}$; b) mechanization and equipment - purchase of moto-cultivator, atomizer (borne) and lawnmowers (borne); purchase of submersible electric pump of $2.2 \mathrm{KW}$ and system for drip irrigation that would be also in function of fertigation $(4,000 \mathrm{~m}$ of pipe lines, $100 \mathrm{~m}$ of laterals, couplings, tank for fertilizer liquefying, etc.); purchase of poles, wire and other support materials; purchase of packaging (5,000 returnable, plastic crates with capacity of 3

7 Mechanization used in agriculture is mainly driven by fossil fuels, contributing to enlargement of greenhouse gas emissions and acceleration of climate change. Mentioned environmental extermination could be alleviated by the use of renewable resources as like solar, wind, biomass, tidal, geo-thermal, bio-fuels, wave-generated power, etc, which have enormous potential for the development of agriculture and processing industry (Chel, Kaushik, 2011).

8 National strategic documents for the use of renewable energy that are in line to EU regulation obliged Serbia to reduce the level of GHGs emissions and increase the share of used energy from renewable sources for $20 \%$ up to the end of current decade (Ašonja et al., 2016).

EP 2017 (64) 2 (821-843) 
$\mathrm{kg}$ ); and possibly purchase of solar electric generator with car trailer ${ }^{9}$; c) plantation - purchase of seedlings (according to the planned planting density $2.5 \times 0.25 \mathrm{~m}$ it is necessary to provide around 16,000 seedlings/ha, where all seedlings has to be certified); d) other costs - costs of irrigation system implementation (setting up and joining of pipes); costs of ground preparation - mechanized (cutting down old plantation, ground clearing from tree stumps and flattening, etc.), plantation establishment (setting up poles and planting of seedlings) and mechanized grassing of inter row space (including the purchase of high-quality grass seed mixture); and possibly the costs of energy infrastructure implementation (digging of channels, purchase and cable installing) and obtaining of all permits and approvals.

Table 3. Investment in new fixed assets (in RSD)

\begin{tabular}{|l|r|r|}
\hline \multicolumn{1}{|c|}{ Element } & Scenario 1 & \multicolumn{1}{c|}{ Scenario 2 } \\
\hline Roto-tiller & $589,000.00$ & $589,000.00$ \\
\hline Atomizer & $124,000.00$ & $124,000.00$ \\
\hline Lawnmower & $62,000.00$ & $62,000.00$ \\
\hline Costs of well establishment & $279,000.00$ & $279,000.00$ \\
\hline Submersible water pump & $55,800.00$ & $55,800.00$ \\
\hline Irrigation system & $235,000.00$ & $235,000.00$ \\
\hline Poles and wire & $310,000.00$ & $310,000.00$ \\
\hline Crates & $250,000.00$ & $250,000.00$ \\
\hline Seedlings & $832,000.00$ & $832,000.00$ \\
\hline Costs of terrain prearrangement & $173,600.00$ & $173,600.00$ \\
\hline Costs of plantation establishment & $217,000.00$ & $217,000.00$ \\
\hline Grassing the inter-row space & $37,200.00$ & $37,200.00$ \\
\hline Implementation of drip irrigation system & $24,800.00$ & $24,800.00$ \\
\hline Establishment of electric power system & $372,000.00$ & - \\
\hline Solar mobile robotized electro-generator & & - \\
\hline Total & $3,561,400.00$ & $1,023,000.00$ \\
\hline
\end{tabular}

Source: authors calculations according to IEP, 2016.

All necessary equipment, materials, seedlings and mechanization would be purchased directly from the producers or targeted distributors/importers at national market with the delivery clause ex-farm, while the realization of all services will entail engagement of external labor. The value of total investment in plantation establishment and purchasing of required mechanization and equipment, as well as investment in PWC are presented in following table (Table 4.).

9 Mobile solar electric generator has capacity of $3 \mathrm{~kW}$. It possess the capacity determined by the capacity of the battery used for storing electric energy (capacity of $480 \mathrm{Ah}$ and voltage of $24 \mathrm{~V}$ ), as well as by the dose of daily solar radiation. Provided energy is ideal for starting the water pumps with power of 1-4 kW. Stored energy in symbiosis with the energy collected on photovoltaic panels, in the climatic conditions of Serbia, during the growing season of raspberries, together with adequate discharge of batteries can provide continuous irrigation of production parcel for the period of around ten hours. After that, batteries have to be additionally recharged (IEP, 2015). 
Table 4. Total investment in establishment of raspberry plantation (in RSD)

\begin{tabular}{|c|l|r|r|r|r|}
\hline \multirow{2}{*}{ No. Element } & \multicolumn{2}{c|}{ Scenario 1 } & \multicolumn{2}{c|}{ Scenario 2 } \\
\cline { 3 - 6 } & & $\begin{array}{c}\text { Total } \\
\text { investment }\end{array}$ & Share (\%) & $\begin{array}{c}\text { Total } \\
\text { investment }\end{array}$ & Share (\%) \\
\hline I & Fixed assets & $\mathbf{3 , 5 6 1 , 4 0 0 . 0 0}$ & $\mathbf{9 0 . 9 1}$ & $\mathbf{4 , 2 1 2 , 4 0 0 . 0 0}$ & $\mathbf{9 0 . 9 1}$ \\
\hline 1. & Facilities & $279,000.00$ & $\mathbf{7 . 1 2}$ & $279,000.00$ & $\mathbf{6 . 0 2}$ \\
\hline 2. & Equipment and mechanization & $1,625,800.00$ & $\mathbf{4 1 . 5 0}$ & $2,648,800.00$ & $\mathbf{5 7 . 1 6}$ \\
\hline 4. & Plantation & $832,000.00$ & $\mathbf{2 1 . 2 4}$ & $832,000.00$ & $\mathbf{1 7 . 9 6}$ \\
\hline 5. & Land & 0.00 & $\mathbf{0 . 0 0}$ & 0.00 & $\mathbf{0 . 0 0}$ \\
\hline 6. & Other & $824,600.00$ & $\mathbf{2 1 . 0 5}$ & $452,600.00$ & $\mathbf{9 . 7 7}$ \\
\hline II & Permanent working capital & $\mathbf{3 5 6 , 1 4 0 . 0 0}$ & $\mathbf{9 . 0 9}$ & $\mathbf{4 2 1 , 2 4 0 . 0 0}$ & $\mathbf{9 . 0 9}$ \\
\hline \multicolumn{1}{|c|}{ Total } & & $\mathbf{3 , 9 1 7 , 5 4 0 . 0 0}$ & $\mathbf{1 0 0 . 0 0}$ & $\mathbf{4 , 6 3 3 , 6 4 0 . 0 0}$ & $\mathbf{1 0 0 . 0 0}$ \\
\hline
\end{tabular}

Source: authors calculations according to IEP, 2016.

Total investments within the observed scenarios differ in absolute value for more than $18 \%$ in favor to Scenario 2, whereby the basic difference within the total investment structure is in line to slightly higher share of equipment and mechanization in the Scenario 2, or to higher share of investment in other fixed assets in Scenario 1. One of the rules from accounting practice says that the amount of required permanent working capital (PWC) is primarily determined in relation to the value of total investment in new fixed assets. In case of plantation establishment and purchase of required equipment and mechanization, it amounts $10 \%$ of the total value of fixed assets.

The part of investment into the fixed assets (purchase of irrigation system and water pump, as well as possible investment in solar electric generator) will be financed from the credit arrangement, while other fixed assets and entire amount of PWC will be financed by own capital (Table 5.). Scenario 1 considers about 7.5\% of total investments financed by external capital, while in case of Scenario 2 this share is almost 4 times higher. Collateral will be against the mortgage on land parcel and available real estate owned by agricultural holding.

Table 5. Financial resources (in RSD)

\begin{tabular}{|c|l|r|r|r|r|}
\hline \multirow{2}{*}{ No. Element } & \multicolumn{2}{c|}{ Scenario 1 } & \multicolumn{2}{c|}{ Scenario 2 } \\
\cline { 3 - 6 } & & $\begin{array}{c}\text { Total } \\
\text { investment }\end{array}$ & Share (\%) & $\begin{array}{c}\text { Total } \\
\text { investment }\end{array}$ & Share (\%) \\
\hline I & Own capital & $\mathbf{3 , 6 2 6 , 7 4 0 . 0 0}$ & $\mathbf{9 2 . 5 8}$ & $\mathbf{3 , 3 1 9 , 8 4 0 . 0 0}$ & $\mathbf{7 1 . 6 5}$ \\
\hline 1. & Fixed assets & $3,270,600.00$ & 83.49 & $2,898,600.00$ & 62.56 \\
\hline 2. & Permanent working capital & $356,140.00$ & 9.09 & $421,240.00$ & 9.09 \\
\hline II & External capital & $\mathbf{2 9 0 , 8 0 0 . 0 0}$ & $\mathbf{7 . 4 2}$ & $\mathbf{1 , 3 1 3 , 8 0 0 . 0 0}$ & $\mathbf{2 8 . 3 5}$ \\
\hline 1. & Fixed assets & $290,800.00$ & 7.42 & $1,313,800.00$ & 28.35 \\
\hline \multicolumn{2}{|c|}{ Total $($ I+II) } & $\mathbf{3 , 9 1 7 , 5 4 0 . 0 0}$ & $\mathbf{1 0 0 . 0 0}$ & $\mathbf{4 , 6 3 3 , 6 4 0 . 0 0}$ & $\mathbf{1 0 0 . 0 0}$ \\
\hline
\end{tabular}

Source: authors calculations according to IEP, 2016.

For both investment projects, agricultural holding could lend from banks at the interest rate of 7\% (Table 6.), while own invested capital will be valued by current a-vista interest rate. Reconsidering assumed interest rates and structure of sources of financing, assessment of economic justification of investment will be based on discount rate of $1.45 \%$, or $2.70 \%$. 
Table 6. Assumed investment structure (in RSD)

\begin{tabular}{|l|r|r|r|r|r|r|}
\hline \multirow{2}{*}{$\begin{array}{c}\text { Source of } \\
\text { financing }\end{array}$} & \multicolumn{3}{|c|}{ Scenario 1 } & \multicolumn{3}{c|}{ Scenario 2 } \\
\cline { 2 - 7 } & $\begin{array}{c}\text { Share } \\
\mathbf{( \% )}\end{array}$ & $\begin{array}{c}\text { Nominal } \\
\text { interest rate } \\
\mathbf{( \% )}\end{array}$ & $\begin{array}{c}\text { Discount } \\
\text { rate (\%) }\end{array}$ & $\begin{array}{c}\text { Share } \\
(\%)\end{array}$ & $\begin{array}{c}\text { Nominal } \\
\text { interest rate } \\
\mathbf{( \% )}\end{array}$ & $\begin{array}{c}\text { Discount } \\
\text { rate (\%) }\end{array}$ \\
\hline Own capital & 92.58 & 1 & 0.9258 & 71.65 & 1 & 0.7165 \\
\hline External capital & 7.42 & 7 & 0.5194 & 28.35 & 7 & 1.9845 \\
\hline Total investment & $\mathbf{1 0 0 . 0 0}$ & $*$ & $\mathbf{1 . 4 4 5 2}$ & $\mathbf{1 0 0 . 0 0}$ & $\mathbf{1 0 0 . 0 0}$ & $\mathbf{2 . 7 0 1}$ \\
\hline
\end{tabular}

Source: authors calculations according to IEP, 2016.

The total income (Table 7.), for both analyzed scenarios, for the project lifetime, would be based on the following assumptions: a) Expected yields and redemption price: Willamette variety will be planted. The income projections are in line with expected yields in the first (10 $\mathrm{t})$, second (12 t) and the rest years (15 t) after plantation establishment. Average redemption price (200 RSD/kg of raspberry in the moment of picking) for the previous five-year period. After picking, the fruit will be directed to local cold storage, as the holding has already precontracted general terms with them; b) Considering the duration of credit arrangement, economic assessment of plantation establishment will cover five years period; c) As in focus is registered agricultural holding that has not an active status, all calculation exclude eventual claims from the relevant Ministry or some other subsidies for plantation establishment, purchase of mechanization and equipment, as well as raspberry production.

Table 7. Income during the investment use (in RSD)

\begin{tabular}{|c|c|c|c|c|}
\hline Element & $\mathbf{U M}$ & Price/UM & Quantity & Total \\
\hline \multicolumn{5}{|c|}{ First year of project (I) } \\
\hline \multicolumn{4}{|c|}{ Incomes of product realization (selling) } & $2,000,000.00$ \\
\hline Raspberry (1 ha) & $\mathrm{kg}$ & 200.00 & $10,000.00$ & $2,000,000.00$ \\
\hline Subsidies & RSD & - & - & \\
\hline \multicolumn{4}{|l|}{ Total (first year) } & $2,000,000.00$ \\
\hline \multicolumn{5}{|c|}{ Second year of project (II) } \\
\hline \multicolumn{4}{|c|}{ Incomes of product realization (selling) } & $2,400,000.00$ \\
\hline Raspberry (1 ha) & $\mathrm{kg}$ & 200.00 & $12,000.00$ & $2,400,000.00$ \\
\hline Subsidies & RSD & - & - & - \\
\hline \multicolumn{4}{|l|}{ Total (second year) } & $2,400,000.00$ \\
\hline \multicolumn{5}{|c|}{$\begin{array}{ll}\text { Third year of project (III) } \\
\end{array}$} \\
\hline \multicolumn{4}{|c|}{ Incomes of product realization (selling) } & $3,000,000.00$ \\
\hline Raspberry (1 ha) & $\mathrm{kg}$ & 200.00 & $15,000.00$ & $3,000,000.00$ \\
\hline Subsidies & RSD & - & - & - \\
\hline \multicolumn{4}{|l|}{ Total (third year) } & $3,000,000.00$ \\
\hline \multicolumn{5}{|c|}{ Fourth year of project (IV) } \\
\hline \multicolumn{4}{|c|}{ Incomes of product realization (selling) } & $3,000,000.00$ \\
\hline Raspberry (1 ha) & $\mathrm{kg}$ & 200.00 & $15,000.00$ & $3,000,000.00$ \\
\hline Subsidies & RSD & - & - & - \\
\hline \multicolumn{4}{|l|}{ Total (fourth year) } & $3,000,000.00$ \\
\hline \multicolumn{5}{|c|}{$\begin{array}{ll}\text { Fifth year of project }(\mathrm{V}) \\
\end{array}$} \\
\hline \multicolumn{4}{|c|}{ Incomes of product realization (selling) } & $3,000,000.00$ \\
\hline
\end{tabular}




\begin{tabular}{|l|c|r|r|r|}
\hline \multicolumn{1}{|c|}{ Element } & UM & Price/UM & Quantity & \multicolumn{1}{c|}{ Total } \\
\hline Raspberry (1 ha) & $\mathrm{kg}$ & 200.00 & $15,000.00$ & $3,000,000.00$ \\
\hline Subsidies & RSD & - & - & - \\
\hline Total (fifth year) & & \\
\hline
\end{tabular}

Source: authors calculations according to IEP, 2016.

In following tables (Tables 8-16.) is presented the structure of costs for the period of project exploitation. Observed period is overlapping the period of credit arrangement (five years).

Table 8. Costs of direct material (in RSD)

\begin{tabular}{|l|r|r|r|r|r|}
\hline \multirow{2}{*}{\multicolumn{1}{|c|}{ Element }} & \multicolumn{5}{c|}{ Years of project } \\
\cline { 2 - 6 } & \multicolumn{1}{|c|}{ I } & \multicolumn{1}{c|}{ II } & \multicolumn{1}{c|}{ III } & \multicolumn{1}{c|}{ IV } & \multicolumn{1}{c|}{ V } \\
\hline Seedlings & $7,800.00$ & $7,800.00$ & $7,800.00$ & $7,800.00$ & $7,800.00$ \\
\hline Mineral fertilizers & $30,800.00$ & $80,400.00$ & $86,800.00$ & $86,800.00$ & $86,800.00$ \\
\hline Manure & $60,000.00$ & - & - & - & - \\
\hline Pesticides & $111,600.00$ & $111,600.00$ & $111,600.00$ & $111,600.00$ & $111,600.00$ \\
\hline Total & $\mathbf{2 1 0 , 2 0 0 . 0 0}$ & $\mathbf{1 9 9 , 8 0 0 . 0 0}$ & $\mathbf{2 0 6 , 2 0 0 . 0 0}$ & $\mathbf{2 0 6 , 2 0 0 . 0 0}$ & $\mathbf{2 0 6 , 2 0 0 . 0 0}$ \\
\hline
\end{tabular}

Source: authors calculations according to IEP, 2016.

Conducted calculations are assuming the following projections of values for direct material: a) Seedlings (for replacement) - assumption is that in each production year plantation will be burdened with replacement of 150 seedlings which for some reason are not in fertility function (caused by drying, mechanical damage, etc.); b) Manure - it is planned at the quantity of $30 \mathrm{t}$ (bovine manure just before planting). The manure would be collected from the local livestock farms; c) Mineral fertilizers - according to common practice, recommendations from the field and yielding potential of used variety of raspberry, planned production requires timeless fertilization with the strict adherence to proposed norms according to the good agricultural practice. During the first and the second year of plantation exploitation, it would be applied $400 \mathrm{~kg}$ of the complex NPK fertilizer (8-11-23), while in the second year would be additionally applied complex water-soluble fertilizers in certain stages of plants growth and development (14-11-25/24-8-16/10-5-26). In third year, when the full yielding is achieved, additionally will be included a $200 \mathrm{~kg} / \mathrm{ha}$ of KAN. For the calculation of mineral fertilizers costs, as the initial price has been taken current retail price from the local distributors of agricultural inputs; d) Pesticides - the use of pesticides would be generally adjusted to the cultivated fruit culture and production conditions (prevention and elimination of weed, diseases and pests). After consultation with representatives of renowned national pesticide producer, the holding has been chosen their full raspberry protection program, where all products would be purchased in local agricultural pharmacy at current retail prices. The principles of integrated production require strictly following the rules regarding the number of treatments, dosage of pesticides, time and way of applications, the waiting period, the environment protection, etc. According to current practice and after considering production conditions in a given year, the agricultural holding would generally apply seven combined and mechanized (with atomizer) pesticides treatments. Herbicides are not included, with the respect to the decision of inter row space grassing. In the range of 
used fungicides are Cuprozin 35 WP, Blue oil, Akord, Pehar, Promesa, Dional 500 SC and Atlas. Among insecticides are Fobos EC, Abastate and Kozak. Bio-immune stimulators as Epin extra and Cirkon would be also used.

Table 9. Costs of energy (in RSD)

\begin{tabular}{|l|r|r|r|r|r|r|}
\hline \multirow{2}{*}{ Element } & \multicolumn{5}{c|}{ Years of project } \\
\cline { 2 - 7 } & \multicolumn{1}{|c|}{ I } & \multicolumn{1}{|c|}{ II } & \multicolumn{1}{|c|}{ III } & \multicolumn{1}{c|}{ IV } & \multicolumn{1}{c|}{ V } \\
\hline \multicolumn{7}{|c|}{ Scenario I } \\
\hline Electric energy & $21,500.00$ & $21,500.00$ & $21,500.00$ & $21,500.00$ & $21,500.00$ \\
\hline Fuel (diesel) & $138,250.00$ & $138,250.00$ & $138,250.00$ & $138,250.00$ & $138,250.00$ \\
\hline Total & $\mathbf{1 5 9 , 7 5 0 . 0 0}$ & $\mathbf{1 5 9 , 7 5 0 . 0 0}$ & $\mathbf{1 5 9 , 7 5 0 . 0 0}$ & $\mathbf{1 5 9 , 7 5 0 . 0 0}$ & $\mathbf{1 5 9 , 7 5 0 . 0 0}$ \\
\hline \multicolumn{7}{|c|}{ Scenario II } \\
\hline Fuel (diesel) & $135,750.00$ & $135,750.00$ & $135,750.00$ & $135,750.00$ & $135,750.00$ \\
\hline Total & $\mathbf{1 3 5 , 7 5 0 . 0 0}$ & $\mathbf{1 3 5 , 7 5 0 . 0 0}$ & $\mathbf{1 3 5 , 7 5 0 . 0 0}$ & $\mathbf{1 3 5 , 7 5 0 . 0 0}$ & $\mathbf{1 3 5 , 7 5 0 . 0 0}$ \\
\hline
\end{tabular}

Source: authors calculations according to IEP, 2016.

Energy consumption is allocated from two sources (Table 9.). Consumption of diesel is related to use of mechanization during the production process (transport and distribution of mineral fertilizers, roto-tilling, spraying pesticides, mowing, transport of harvested (picked) fruits, transportation of necessary materials, etc.), while consumption of electricity is related to the functioning of irrigation systems and filling of the pesticides tank with water. Transport will be done by the van (Scenario 1), or by the car trailer (mobile platform of the solar generator) in the case of Scenario 2. Also, all needed electric power in second scenario would be provided from the solar generator. It should be underlined that dislocation of production parcel, out of the economic yard at Scenario 1 considers installing of new electric meter that will be related to the current raspberry production, so the payment of electric power assumes higher (industrial) tariff.

Table 10. Other material costs (in RSD)

\begin{tabular}{|l|r|r|r|r|r|}
\hline \multirow{2}{*}{ Element } & \multicolumn{5}{|c|}{ Years of project } \\
\cline { 2 - 6 } & \multicolumn{1}{|c|}{ I } & \multicolumn{1}{|c|}{ II } & \multicolumn{1}{c|}{ III } & \multicolumn{1}{c|}{ IV } & V \\
\hline Rope & $4,930.00$ & $4,930.00$ & $4,930.00$ & $4,930.00$ & $4,930.00$ \\
\hline Agri-chemical analysis of soil & - & - & $6,175.00$ & $6,175.00$ & $6,175.00$ \\
\hline $\begin{array}{l}\text { Material costs of equipment and } \\
\text { mechanization maintenance }\end{array}$ & $7,500.00$ & $7,500.00$ & $7,500.00$ & $7,500.00$ & $7,500.00$ \\
\hline Total & $\mathbf{1 2 , 4 3 0 . 0 0}$ & $\mathbf{1 2 , 4 3 0 . 0 0}$ & $\mathbf{1 8 , 6 0 5 . 0 0}$ & $\mathbf{1 8 , 6 0 5 . 0 0}$ & $\mathbf{1 8 , 6 0 5 . 0 0}$ \\
\hline
\end{tabular}

Source: authors calculations according to IEP, 2016.

Other material costs (Table 10.) include annual costs of maintenance (regular service) and minor repairs on used mechanization and equipment. Also, they would cover the annual costs of pedological and agro-chemical soil analysis (from the aspect of potential changes within the planned fertilization program), as well as costs of purchased rope for binding. 
Table 11. Depreciation of investment project (in RSD)

\begin{tabular}{|c|c|c|c|c|c|c|}
\hline Element & Purchase value & $\begin{array}{c}\text { Lifetime of } \\
\text { assets (years) }\end{array}$ & $\begin{array}{c}\text { Depreciation } \\
\text { rate }(\%)\end{array}$ & $\begin{array}{c}\text { Annual } \\
\text { depreciation }\end{array}$ & $\begin{array}{c}\text { Period } \\
\text { of credit } \\
\text { repayment } \\
\text { (years) }\end{array}$ & $\begin{array}{l}\text { Ultimate value } \\
\text { of investment }\end{array}$ \\
\hline \multicolumn{7}{|c|}{ Scenario 1} \\
\hline Facilities & $279,000.00$ & 40 & 2.50 & $6,975.00$ & 5 & $244,125.00$ \\
\hline $\begin{array}{l}\text { Equipment and } \\
\text { mechanization }\end{array}$ & $1,625,800.00$ & 10 & 10.00 & $162,580.00$ & 5 & $812,900.00$ \\
\hline Plantation & $832,000.00$ & 15 & 6.67 & $55,466.67$ & 5 & $554,666.67$ \\
\hline Other & $824,600.00$ & 5 & 20.00 & $164,920.00$ & 5 & 0.00 \\
\hline Fixed assets & - & - & - & $389,941.67$ & - & $1,611,691.67$ \\
\hline PWC & $356,140.00$ & - & - & - & - & $356,140.00$ \\
\hline \multicolumn{2}{|c|}{ Ultimate value of investment } & - & - & - & - & $1,967,831.67$ \\
\hline \multicolumn{7}{|c|}{ Scenario 2} \\
\hline Facilities & $279,000.00$ & 40 & 2.50 & $6,975.00$ & 5 & $244,125.00$ \\
\hline $\begin{array}{l}\text { Equipment and } \\
\text { mechanization }\end{array}$ & $2,648,800.00$ & 10 & 10.00 & $264,880.00$ & 5 & $1,324,400.00$ \\
\hline Plantation & $832,000.00$ & 15 & 6.67 & $55,466.67$ & 5 & $554,666.67$ \\
\hline Other & $452,600.00$ & 5 & 20.00 & $90,520.00$ & 5 & 0.00 \\
\hline Fixed assets & - & - & - & $417,841.67$ & - & $2,123,191.67$ \\
\hline PWC & \begin{tabular}{|r|}
$421,240.00$ \\
\end{tabular} & - & - & - & - & $421,240.00$ \\
\hline \multicolumn{2}{|c|}{ Ultimate value of investment } & - & - & - & - & $2,544,431.67$ \\
\hline
\end{tabular}

Source: authors calculations according to IEP, 2016.

The depreciation rate is determined by the assumed lifetime of the investment objects (Table 11.), e.g. for the raspberry plantation, it was projected at 15 years. The salvage value of the investment is in line with the duration of the loan arrangement. It should be noted that calculation of depreciation includes only general cost price (without VAT) of purchased and established/implemented fixed asset and equipment. It was used the linear depreciation model with depreciation rate of 2.50 to $20 \%$. The difference in the salvage values' of the projects (between the observed scenarios) is primarily contained in additional investment in solar electric generator.

Table 12. Costs of labor (in RSD)

\begin{tabular}{|c|c|c|c|}
\hline Element & $\begin{array}{c}\text { Number of } \\
\text { needed wages }\end{array}$ & $\begin{array}{c}\text { Average value of gross } \\
\text { wage }\end{array}$ & Total labor costs \\
\hline Costs of seasonal labor & 310 & $2,000.00$ & $620,000.00$ \\
\hline
\end{tabular}

Source: authors calculations according to IEP, 2016.

Necessary operations during the production will involve employment of holding members in the activities of transport and manipulation by mineral fertilizers, pesticides and other agricultural inputs, as well as their application. Also, they will be involved in the activities of soil tillage and cultivation, grass mowing, planting of new seedlings as the replacement, starting and supervision of the irrigation system functioning, organization of harvest (picking) and transport of fruits to the purchasers, administrative issues, etc. During the season of by labor more intensive activities, agricultural holding would be 
hired certain number of external (seasonal) workers (price of labor is determined by the average value of the wage for observed activities at wider city area). Conducting the daily duties, engaged labor will comply with all regulations related to protection of persons, property and environmental elements. They will be mainly engaged at hoeing, removal of old (yielding) shoots, corrective thinning of young shoots, picking and manipulation with fruits, etc. (Table 12.).

Table 13. Repayment plan (in RSD)

\begin{tabular}{|c|r|r|r|r|}
\hline Year of project & $\begin{array}{c}\text { The rest of the } \\
\text { debt }\end{array}$ & \multicolumn{1}{|c|}{ Interest } & Debt repayment & $\begin{array}{c}\text { Instalment } \\
\text { (annuity) }\end{array}$ \\
\hline \multicolumn{5}{|c|}{ Scenario 1 } \\
\hline I & $311,156.00$ & 0.00 & 0.00 & 0.00 \\
\hline II & $241,267.67$ & $19,972.88$ & $69,888.32$ & $89,861.20$ \\
\hline III & $166,357.24$ & $14,950.76$ & $74,910.44$ & $89,861.20$ \\
\hline IV & $86,063.81$ & $9,567.77$ & $80,293.43$ & $89,861.20$ \\
\hline V & 0.57 & $3,797.97$ & $86,063.23$ & $89,861.20$ \\
\hline \multicolumn{5}{|c|}{ Scenario 2 } \\
\hline I & $1,405,766.00$ & 0.00 & 0.00 & 0.00 \\
\hline II & $1,090,018.26$ & $90,235.07$ & $315,747.74$ & $405,982.80$ \\
\hline III & $751,581.19$ & $67,545.72$ & $338,437.08$ & $405,982.80$ \\
\hline IV & $388,824.36$ & $43,225.97$ & $362,756.83$ & $405,982.80$ \\
\hline V & 0.00 & $17,158.62$ & $388,824.18$ & $405,982.80$ \\
\hline
\end{tabular}

Source: authors calculations according to IEP, 2016.

Repayment of credit is followed by next projections (Table 13.): specialized credit in RSD will be provided by commercial bank; credit will be used for purchase of irrigation system, water pump and solar electric generator; with fixed interest rate of $7 \%$; interest on credit will be calculated by simple method and credit repayment will be in equal annuities (quarterly); credit duration will be for five years, with grace period of one year; interest on credit will be also calculated during the period of credit inaction. Difference between calculated annuities for observed scenarios comes from difference of initial debit.

Table 14. Other immaterial costs (in RSD)

\begin{tabular}{|l|r|r|r|r|r|}
\hline \multirow{2}{*}{ Element } & \multicolumn{5}{c|}{ Year of project } \\
\cline { 2 - 6 } \multicolumn{1}{|c|}{ I } & \multicolumn{1}{|c|}{ II } & \multicolumn{1}{c|}{ III } & \multicolumn{1}{c|}{ IV } & \multicolumn{1}{c|}{ V } \\
\hline Insurance & $133,300.00$ & $133,300.00$ & $133,300.00$ & $133,300.00$ & $133,300.00$ \\
\hline Other immaterial costs & $46,750.00$ & $46,750.00$ & $46,750.00$ & $46,750.00$ & $46,750.00$ \\
\hline Total & $\mathbf{1 7 9 , 0 5 0 . 0 0}$ & $\mathbf{1 7 9 , 0 5 0 . 0 0}$ & $\mathbf{1 7 9 , 0 5 0 . 0 0}$ & $\mathbf{1 7 9 , 0 5 0 . 0 0}$ & $\mathbf{1 7 9 , 0 5 0 . 0 0}$ \\
\hline
\end{tabular}

Source: authors calculations according to IEP, 2016.

Raspberry requires the low intensity but constant irrigation, causing a consumption of large amounts of water, holding would not be burdened by the costs for water as it is drawn from holdings' own well (Table 14.). Since it was estimated that a safety nets are not necessary for the production process, in order to protect the production from the risk of adverse climatic factors (hail), holding will insure the entire plantation at the insurance company. Other intangible costs would imply annual costs (fee) of 
production parcel drainage, part of holdings' overheads, fees and taxes on real estate's related to the production process, etc.

Table 15. Total costs of raspberry plantation establishment (in RSD)

\begin{tabular}{|c|c|c|c|c|c|}
\hline \multirow{2}{*}{ Element } & \multicolumn{5}{|c|}{ Year of project } \\
\hline & I & II & III & IV & $\mathbf{V}$ \\
\hline \multicolumn{6}{|c|}{ Scenario 1} \\
\hline I Material costs & $382,380.00$ & $371,980.00$ & $384,555.00$ & $384,555.00$ & $384,555.00$ \\
\hline Direct material & $210,200.00$ & $199,800.00$ & $206,200.00$ & $206,200.00$ & $206,200.00$ \\
\hline Energy & $159,750.00$ & $159,750.00$ & $159,750.00$ & $159,750.00$ & $159,750.00$ \\
\hline Other material costs & $12,430.00$ & $12,430.00$ & $18,605.00$ & $18,605.00$ & $18,605.00$ \\
\hline II Immaterial costs & $1,188,991.67$ & $1,208,964.55$ & $1,203.942 .43$ & $1,198.559 .44$ & $1,192,789.64$ \\
\hline Depreciation & $389,941.67$ & $389,941.67$ & $389,941.67$ & $389,941.67$ & $389,941.67$ \\
\hline Labor & $620,000.00$ & $620,000.00$ & $620,000.00$ & $620,000.00$ & $620,000.00$ \\
\hline Interest (credit) & 0.00 & $19,972.88$ & $14,950.76$ & $9,567.77$ & $3,797.97$ \\
\hline Other immaterial costs & $179,050.00$ & $179,050.00$ & $179,050.00$ & $179,050.00$ & $179,050.00$ \\
\hline Total (I+II) & $1,571,371.67$ & $1,580,944.55$ & $1,588,497.43$ & $1,583,114.44$ & $1,577,344.64$ \\
\hline \multicolumn{6}{|c|}{ Scenario 2} \\
\hline I Material costs & $358,380.00$ & $347,980.00$ & $360,555.00$ & $360,555.00$ & $360,555.00$ \\
\hline Direct material & $210,200.00$ & $199,800.00$ & $206,200.00$ & $206,200.00$ & $206,200.00$ \\
\hline Energy & $135,750.00$ & $135,750.00$ & $135,750.00$ & $135,750.00$ & $135,750.00$ \\
\hline Other material costs & $12,430.00$ & $12,430.00$ & $18,605.00$ & $18,605.00$ & $18,605.00$ \\
\hline II Immaterial costs & $1,216,891.67$ & $1,307,126.74$ & $1,284,437.39$ & $1,260,117.64$ & $1,234,050.29$ \\
\hline Depreciation & $417,841.67$ & $417,841.67$ & $417,841.67$ & $417,841.67$ & $417,841.67$ \\
\hline Labor & $620,000.00$ & $620,000.00$ & $620,000.00$ & $620,000.00$ & $620,000.00$ \\
\hline Interest (credit) & 0.00 & $90,235.07$ & $67,545.72$ & $43,225.97$ & $17,158.62$ \\
\hline Other immaterial costs & $179,050.00$ & $179,050.00$ & $179,050.00$ & $179,050.00$ & $179,050.00$ \\
\hline Total (I+II) & $1,575,271.67$ & $1,655,106.74$ & $1,644,992.39$ & $1,620,672.64$ & $1,594,605.29$ \\
\hline
\end{tabular}

Source: authors calculations according to IEP, 2016.

In Table 15. is presented the structure of the total costs of establishment and exploitation of raspberry plantation, together with purchase of equipment and mechanization during the period of credit lifetime. For both scenarios, within the each production year there is noticeable domination of the total intangible under material costs, directly caused by the height of labor costs and value of depreciation.

Table 16. Profit and loss statement (in RSD)

\begin{tabular}{|c|c|c|c|c|c|c|}
\hline \multirow{2}{*}{ No } & \multirow{2}{*}{ Element } & \multicolumn{5}{|c|}{ Year of project } \\
\hline & & I & II & III & IV & $\mathbf{V}$ \\
\hline \multicolumn{7}{|c|}{ Scenario 1} \\
\hline I & Total revenues & $2,000,000.00$ & $2,400,000.00$ & $3,000,000.00$ & $3,000,000.00$ & $3,000,000.00$ \\
\hline 1. & Revenues from sales & $2,000,000.00$ & $2,400,000.00$ & $3,000,000.00$ & $3,000,000.00$ & $3,000,000.00$ \\
\hline 2. & Subsidies & 0.00 & 0.00 & 0.00 & 0.00 & 0.00 \\
\hline 3. & Other revenues & 0.00 & 0.00 & 0.00 & 0.00 & 0.00 \\
\hline II & Total expenses & $1,571,371.67$ & $1,580,944.55$ & $1,588,497.43$ & $1,583,114.44$ & $1,577,344.64$ \\
\hline 1. & Operational costs & $1,571,371.67$ & $1,560,971.67$ & $1,573,546.67$ & $1,573,546.67$ & $1,573,546.67$ \\
\hline 1.1. & Material costs & $382,380.00$ & $371,980.00$ & $384,555.00$ & $384,555.00$ & $384,555.00$ \\
\hline 1.2 . & Immaterial costs* & $799,050.00$ & $799,050.00$ & $799,050.00$ & $799,050.00$ & $799,050.00$ \\
\hline 1.3 . & Depreciation & $389,941.67$ & $389,941.67$ & $389,941.67$ & $389,941.67$ & $389,941.67$ \\
\hline
\end{tabular}




\begin{tabular}{|c|c|c|c|c|c|c|}
\hline \multirow{2}{*}{ No } & \multirow{2}{*}{ Element } & \multicolumn{5}{|c|}{ Year of project } \\
\hline & & $\mathbf{I}$ & II & III & IV & $\mathbf{V}$ \\
\hline 2. & Financial expenses & 0.00 & $19,972.88$ & $14,950.76$ & $9,567.77$ & $3,797.97$ \\
\hline 2.1 . & Interest (credit) & 0.00 & $19,972.88$ & $14,950.76$ & $9,567.77$ & $3,797.97$ \\
\hline III & Gross profit (I-II) & $428,628.33$ & $819,055.45$ & $1,411,502.57$ & $1,416,885.56$ & $1,422,655.36$ \\
\hline IV & Income tax ** & 0.00 & 0.00 & 0.00 & 0.00 & 0.00 \\
\hline $\mathbf{V}$ & Net profit (III-IV) & $428,628.33$ & $819,055.45$ & $1,411,502.57$ & $1,416,885.56$ & $1,422,655.36$ \\
\hline \multicolumn{7}{|c|}{ Scenario 2} \\
\hline $\mathbf{I}$ & Total revenues & $2,000,000.00$ & $2,400,000.00$ & $3,000,000.00$ & $3,000,000.00$ & $3,000,000.00$ \\
\hline 1. & Revenues from sales & $2,000,000.00$ & $2,400,000.00$ & $3,000,000.00$ & $3,000,000.00$ & $3,000,000.00$ \\
\hline 2. & Subsidies & 0.00 & 0.00 & 0.00 & 0.00 & 0.00 \\
\hline 3. & Other revenues & 0.00 & 0.00 & 0.00 & 0.00 & 0.00 \\
\hline II & Total expenses & $1,575,271.67$ & $1,655,106.74$ & $1,644,992.39$ & $1,620,672.64$ & $1,594,605.29$ \\
\hline 1. & Operational costs & $1,575,271.67$ & $1,564,871.67$ & $1,577,446.67$ & $1,577,446.67$ & $1,577,446.67$ \\
\hline 1.1. & Material costs & $358,380.00$ & $347,980.00$ & $360,555.00$ & $360,555.00$ & $360,555.00$ \\
\hline 1.2 . & Immaterial costs* & $799,050.00$ & $799,050.00$ & $799,050.00$ & $799,050.00$ & $799,050.00$ \\
\hline 1.3. & \begin{tabular}{|l|} 
Depreciation \\
\end{tabular} & $417,841.67$ & $417,841.67$ & $417,841.67$ & $417,841.67$ & $417,841.67$ \\
\hline 2. & Financial expenses & 0.00 & $90,235.07$ & $67,545.72$ & $43,225.97$ & $17,158.62$ \\
\hline 2.1. & Interest (credit) & 0.00 & $90,235.07$ & $67,545.72$ & $43,225.97$ & $17,158.62$ \\
\hline III & Gross profit (I-II) & $424,728.33$ & $744,893.26$ & $1,355,007.61$ & $1,379,327.36$ & $1,405,394.71$ \\
\hline IV & Income tax** & 0.00 & 0.00 & 0.00 & 0.00 & 0.00 \\
\hline $\mathbf{V}$ & Net profit (III-IV) & $424,728.33$ & $744,893.26$ & $1,355,007.61$ & $1,379,327.36$ & $1,405,394.71$ \\
\hline
\end{tabular}

Source: authors calculations according to IEP, 2016.

Note: * immaterial costs do not cover depreciation and interest of loan; ** agricultural holding does not belong to VAT system, so does not pay income tax.

According to the previous table (Table 16.), it can be seen that after the establishment of plantation, in both scenarios, holding will achieve the positive financial result in all years within the observed period.

In the next tables (Table 17. and 18.) are shown the cash and economic flows of investment project realization.

Table 17. Cash flow (in RSD)

\begin{tabular}{|c|c|c|c|c|c|c|c|}
\hline \multirow{2}{*}{ No. } & \multirow{2}{*}{ Element } & \multirow{2}{*}{$\begin{array}{c}\text { Initial } \\
\text { moment }\end{array}$} & \multicolumn{5}{|c|}{ Year } \\
\hline & & & I & II & III & IV & $\mathbf{V}$ \\
\hline \multicolumn{8}{|c|}{ Scenario 1} \\
\hline $\mathbf{I}$ & Total income & $3,917,540.00$ & $2,000,000.00$ & $2,400,000.00$ & $3,000,000.00$ & $3,000,000.00$ & $4,967,831.67$ \\
\hline 1. & Total revenues & 0.00 & $2,000,000.00$ & $2,400,000.00$ & $3,000,000.00$ & $3,000,000.00$ & $3,000,000.00$ \\
\hline \multirow{3}{*}{2.} & Source of financing & $3,917,540.00$ & - & - & - & - & - \\
\hline & 2.1. Own capital & $3,626,740.00$ & - & - & - & - & - \\
\hline & 2.2. External capital & $290,800.00$ & - & - & - & - & - \\
\hline \multirow{3}{*}{3.} & $\begin{array}{l}\text { Remaining project } \\
\text { value }\end{array}$ & 0.00 & 0.00 & 0.00 & 0.00 & 0.00 & $1,967,831.67$ \\
\hline & 3.1. Fixed assets & 0.00 & - & - & - & - & $1,611,691.67$ \\
\hline & 3.2. PWC & 0.00 & - & - & - & - & $356,140.00$ \\
\hline II & Total expenditures & $3,917,540.00$ & $1,181,430.00$ & $1,260,891.20$ & $1,273,466.20$ & $1,273,466.20$ & $1,273,466.20$ \\
\hline \multirow{3}{*}{4.} & Value of investment & $3,917,540.00$ & - & - & - & - & - \\
\hline & 4.1. In fixed assets & $3,561,400.00$ & - & - & - & - & - \\
\hline & 4.2. In PWC & $356,140.00$ & - & - & - & - & - \\
\hline
\end{tabular}




\begin{tabular}{|c|c|c|c|c|c|c|c|}
\hline 5. & $\begin{array}{l}\text { Costs without } \\
\text { depreciation and interest }\end{array}$ & 0.00 & $1,181,430.00$ & $1,171,030.00$ & $1,183,605.00$ & $1,183,605.00$ & $1,183,605.00$ \\
\hline 6. & Income tax & 0.00 & 0.00 & 0.00 & 0.00 & 0.00 & 0.00 \\
\hline 7. & Annuities & 0.00 & 0.00 & $89,861.20$ & $89,861.20$ & $89,861.20$ & $89,861.20$ \\
\hline III & Net income (I-II) & 0.00 & $818,570.00$ & $1,139,108.80$ & $1,726,533.80$ & $1,726,533.80$ & $3,694,365.47$ \\
\hline \multicolumn{8}{|c|}{ Scenario 2} \\
\hline $\mathbf{I}$ & Total income & $4,633,640.00$ & $2,000,000.00$ & $2,400,000.00$ & $3,000,000.00$ & $3,000,000.00$ & $5,544,431.67$ \\
\hline 1. & Total revenues & 0.00 & $2,000,000.00$ & $2,400,000.00$ & $3,000,000.00$ & $3,000,000.00$ & $3,000,000.00$ \\
\hline \multirow{3}{*}{2.} & Source offinancing & $4,633,640.00$ & - & - & - & - & - \\
\hline & 2.1. Own capital & $3,319,840.00$ & - & - & - & - & - \\
\hline & 2.2. External capital & $1,313,800.00$ & - & - & - & - & - \\
\hline \multirow{3}{*}{3.} & $\begin{array}{l}\text { Remaining project } \\
\text { value }\end{array}$ & 0.00 & 0.00 & 0.00 & 0.00 & 0.00 & $2,544,431.67$ \\
\hline & 3.1. Fixed assets & 0.00 & - & - & - & - & $2,123,191.67$ \\
\hline & 3.2. $\mathrm{PWC}$ & 0.00 & - & - & - & - & $421,240.00$ \\
\hline II & Total expenditures & $4,633,640.00$ & $1,157,430.00$ & $1,553,012.80$ & $1,565,587.80$ & $1,565,587.80$ & $1,565,587.80$ \\
\hline \multirow{3}{*}{4.} & Value of investment & $4,633,640.00$ & - & - & - & - & - \\
\hline & 4.1. In fixed assets & $4,212,400.00$ & - & - & - & - & - \\
\hline & 4.2. In PWC & $421,240.00$ & - & - & - & - & - \\
\hline 5. & $\begin{array}{l}\text { Costs without } \\
\text { depreciation and interest }\end{array}$ & 0.00 & $1,157,430.00$ & $1,147,030.00$ & $1,159,605.00$ & $1,159,605.00$ & $1,159,605.00$ \\
\hline 6. & Income tax & 0.00 & 0.00 & 0.00 & 0.00 & 0.00 & 0.00 \\
\hline 7. & Annuities & 0.00 & 0.00 & $405,982.80$ & $405,982.80$ & $405,982.80$ & $405,982.80$ \\
\hline III & Net income (I-II) & 0.00 & $842,570.00$ & $846,987.20$ & $1,434,412.20$ & $1,434,412.20$ & $3,978,843.87$ \\
\hline
\end{tabular}

Source: authors calculations according to IEP, 2016.

In all observed years (Table 17.) in both scenarios plantation generates positive net cash flows. It is noticeable the gradual increase in the net incomes within the presented flows, as a result of yield growth during the exploitation of raspberry plantation. Slightly higher net income in single years at Scenario 1 is caused by higher level of indebtedness in case of Scenario 2. Also, at both scenarios there has been relatively higher value of net incomes in last observed year, as a direct consequence of the remained underestimated value of investment project, as the economic analysis is in line with duration of credit arrangement.

Similar comments could be also tied to the results presented in Table 18.

Table 18. Economic flow (in RSD)

\begin{tabular}{|c|c|c|c|c|c|c|c|}
\hline \multirow{2}{*}{ No. } & \multirow{2}{*}{ Element } & \multirow{2}{*}{$\begin{array}{c}\text { Initial } \\
\text { moment }\end{array}$} & \multicolumn{5}{|c|}{ Year } \\
\hline & & & 1 & 2 & 3 & 4 & 5 \\
\hline \multicolumn{8}{|c|}{ Scenario 1} \\
\hline $\mathbf{I}$ & Total income & 0.00 & $2,000,000.00$ & $2,400,000.00$ & $3,000,000.00$ & $3,000,000.00$ & $4,967,831.67$ \\
\hline 1. & Total revenues & 0.00 & $2,000,000.00$ & $2,400,000.00$ & $3,000,000.00$ & $3,000,000.00$ & $3,000,000.00$ \\
\hline \multirow{3}{*}{2.} & $\begin{array}{l}\text { Remaining project } \\
\text { value }\end{array}$ & 0.00 & 0.00 & 0.00 & 0.00 & 0.00 & $1,967,831.67$ \\
\hline & 2.1. Fixed assets & 0.00 & - & - & - & - & $1,611,691.67$ \\
\hline & 2.2. PWC & 0.00 & - & - & - & - & $356,140.00$ \\
\hline II & Total expenditures & $3,917,540.00$ & $1,181,430.00$ & $1,171,030.00$ & $1,183,605.00$ & $1,183,605.00$ & $1,183,605.00$ \\
\hline \multirow{3}{*}{3.} & Value of investment & $3,917,540.00$ & - & - & - & - & - \\
\hline & 3.1. In fixed assets & $3,561,400.00$ & - & - & - & - & - \\
\hline & 3.2. In PWC & $356,140.00$ & - & - & - & - & - \\
\hline 4. & $\begin{array}{l}\text { Costs without } \\
\text { depreciation and interest }\end{array}$ & 0.00 & $1,181,430.00$ & $1,171,030.00$ & $1,183,605.00$ & $1,183,605.00$ & $1,183,605.00$ \\
\hline
\end{tabular}




\begin{tabular}{|c|c|c|c|c|c|c|c|}
\hline 5. & Income tax & 0.00 & 0.00 & 0.00 & 0.00 & 0.00 & 0.00 \\
\hline III & Net income (I-II) & $-3,917,540.00$ & $818,570.00$ & $1,228,970.00$ & $1,816,395.00$ & $1,816,395.00$ & $3,784,226.67$ \\
\hline \multicolumn{8}{|c|}{ Scenario 2} \\
\hline $\mathbf{I}$ & Total income & 0.00 & $2,000,000.00$ & $2,400,000.00$ & $3,000,000.00$ & $3,000,000.00$ & $5,544,431.67$ \\
\hline 1. & Total revenues & 0.00 & $2,000,000.00$ & $2,400,000.00$ & $3,000,000.00$ & $3,000,000.00$ & $3,000,000.00$ \\
\hline \multirow{3}{*}{2.} & $\begin{array}{l}\text { Remaining project } \\
\text { value }\end{array}$ & 0.00 & 0.00 & 0.00 & 0.00 & 0.00 & $2,544,431.67$ \\
\hline & 2.1. Fixed assets & 0.00 & - & - & - & - & $2,123,191.67$ \\
\hline & 2.2. PWC & 0.00 & - & - & - & - & $421,240.00$ \\
\hline II & Total expenditures & $4,633,640.00$ & $1,157,430.00$ & $1,147,030.00$ & $1,159,605.00$ & $1,159,605.00$ & $1,159,605.00$ \\
\hline \multirow{3}{*}{3.} & Value of investment & $4,633,640.00$ & - & - & - & - & - \\
\hline & 3.1. In fixed assets & $4,212,400.00$ & - & - & - & - & - \\
\hline & 3.2. In PWC & $421,240.00$ & - & - & - & - & - \\
\hline 4. & $\begin{array}{l}\text { Costs without } \\
\text { depreciation and interest }\end{array}$ & 0.00 & $1,157,430.00$ & $1,147,030.00$ & $1,159,605.00$ & $1,159,605.00$ & $1,159,605.00$ \\
\hline 5. & Income tax & 0.00 & 0.00 & 0.00 & 0.00 & 0.00 & 0.00 \\
\hline III & Net income (I-II) & $-4,633,640.00$ & $842,570.00$ & $1,252,970.00$ & $1,840,395.00$ & $1,840,395.00$ & $4,384,826.67$ \\
\hline
\end{tabular}

Source: authors calculations according to IEP, 2016.

For reducing the risk of bad investment and credit decisions that could potentially jeopardize the future business, the analysis of economic effectiveness of raspberry plantation establishment and eventual purchase of a mobile robotic solar electro-generator will be done (Tables 19. and 20).

According to dynamic assessment the use of all available methods will adjust the time preference (the time value) of money. In other words, all incomes and expenditures stemmed from the investment, ensued in different time periods, would be brought to the unique moment (usually the present moment - the current value) by the use of discounting technique (Subić, 2010). 


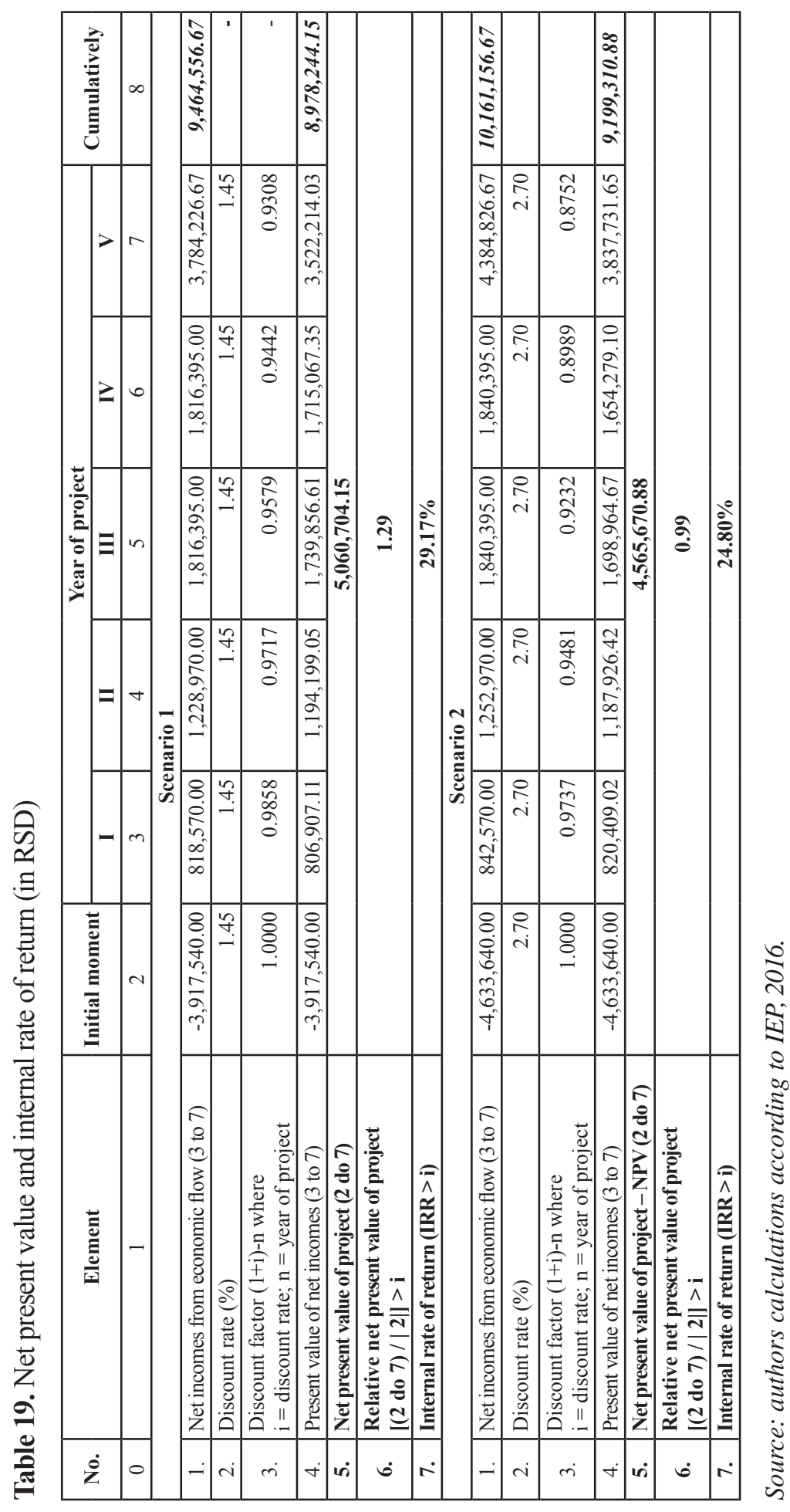

EP 2017 (64) 2 (821-843) 
According to indicators from the Table 19., the following conclusion could be drown:

- Investment in raspberry plantation and purchase of mechanization will enable the holding, up to the final moment of credit repayment (five years), to increase the total income (value of NPV) for 5,060,704.15 RSD (Scenario 1), accounted by discount rate $\mathrm{i}=1.45 \%$ on initial moment (zero moment). In case of Scenario 2 , it could be expected NPV value of $4,565,670.88$ RSD calculated by the discount rate $i=2.70 \%$ on zero moment;

- Values of relative net present value of investment of 1.29 , or 0.99 consider relative increase of accumulation made on holding above the calculative price of financing assets $(1.45 \%$, or $2.70 \%)$, what will provide their covering, as well as achieving certain profit during the project period;

- As the value of IRR has to be higher, or at least equal to the interest rate of borrowed capital and/or weighted interest rate of all used financial sources, it could be concluded that the planned investments have significant level of profitability, as the values for IRR in both cases are few times higher than the mentioned interest rates $(29.17 \%>7.00 \%>$ $1.45 \%$ at Scenario 1 , or $24.80 \%>7.00 \%>2.70 \%$ at Scenario 2 ).

According to values of all presented indicators, agricultural holding could consider both investments as economically justified decision. Slightly better values in Scenario 1 have been compensated by more expressed environmental impact in Scenario 2. Also, overall multi-functionality of the solar electric generator could additionally effect the strengthening of presented indicators' values if it is used on the holding for the activities that are not directly related to the production of raspberries. Additionally its full economic contribution (effect of energy savings) would be visible after the few years of usage.

Table 20. Payback period of investment (in RSD)

\begin{tabular}{|c|r|r|}
\hline Year of project & Present value of net incomes & Cumulative net incomes \\
\hline \multicolumn{3}{|c|}{ Scenario 1 } \\
\hline 0 & $-3,917,540.00$ & $-3,917,540.00$ \\
\hline I & $806,907.11$ & $-3,110,632.89$ \\
\hline II & $1,194,199.05$ & $-1,916,433.84$ \\
\hline III & $1,739,856.61$ & $-176,577.22$ \\
\hline IV & $1,715,067.35$ & $1,538,490.12$ \\
\hline V & $3,522,214.03$ & $5,060,704.15$ \\
\hline & Scenario 2 & $-4,633,640.00$ \\
\hline Or| & $-4,633,640.00$ & $-3,813,230.98$ \\
\hline I & $820,409.02$ & $-2,625,304.56$ \\
\hline II & $1,187,926.42$ & $-926,339.88$ \\
\hline III & $1,698,964.67$ & $727,939.22$ \\
\hline IV & $1,654,279.10$ & $4,565,670.88$ \\
\hline V & $3,837,731.65$ & \\
\hline
\end{tabular}

Source: authors calculations according to IEP, 2016. 
In accordance to gained indicator values (Table 20.), for both observed scenarios derived conclusion could go into the direction of complete economic justification of planned investment (needed period is shorter than the duration of the credit arrangement). Related to indicators' values Scenario 1 could be considered more favorable $(\mathrm{T}=3$ years and 1.24 months $<\mathrm{n}=5$ years) than the Scenario 2 ( $\mathrm{T}=3$ years and 6.71 months $<\mathrm{n}=5$ years).

Table 21. Break-even point (in RSD)

\begin{tabular}{|c|c|c|c|c|c|}
\hline \multirow{2}{*}{ Element } & \multicolumn{5}{|c|}{ Year of project } \\
\hline & I & II & III & IV & $\mathbf{V}$ \\
\hline \multicolumn{6}{|c|}{ Scenario 1} \\
\hline Income (I) & $2,000,000.00$ & $2,400,000.00$ & $3,000,000.00$ & $3,000,000.00$ & $3,000,000.00$ \\
\hline Variable costs (VC) & $1,002,380.00$ & $991,980.00$ & $1,004,555.00$ & $1,004,555.00$ & $1,004,555.00$ \\
\hline Fixed costs (FC) & $179,050.00$ & $179,050.00$ & $179,050.00$ & $179,050.00$ & $179,050.00$ \\
\hline Marginal result $(\mathrm{MR}=\mathrm{I}-\mathrm{VC})$ & $997,620.00$ & $1,408,020.00$ & $1,995,445.00$ & $1,995,445.00$ & $1,995,445.00$ \\
\hline $\begin{array}{l}\text { Break-even point } \\
(\mathrm{BEP}=(\mathrm{FC} / \mathrm{MR}) \times 100),(\text { in } \%)\end{array}$ & 17.95 & 12.72 & 8.97 & 8.97 & 8.97 \\
\hline $\begin{array}{l}\text { Break-even point by value } \\
(\mathrm{BEPv}=(\mathrm{I} \times \mathrm{BEP}) / 100)\end{array}$ & $358,954.31$ & $305,194.53$ & $269,188.08$ & $269,188.08$ & $269,188.08$ \\
\hline $\begin{array}{l}\text { Level of safeness }(\text { in \%) } \\
(\mathrm{LS}=((1-(\mathrm{BEPV} / \mathrm{I})) \times 100)\end{array}$ & 82.05 & 87.28 & 91.03 & 91.03 & 91.03 \\
\hline \multicolumn{6}{|c|}{ Scenario 2} \\
\hline Income (I) & $2,000,000.00$ & $2,400,000.00$ & $3,000,000.00$ & $3,000,000.00$ & $3,000,000.00$ \\
\hline Variable costs (VC) & $978,380.00$ & $967,980.00$ & $980,555.00$ & $980,555.00$ & $980,555.00$ \\
\hline Fixed costs $(\mathrm{FC})$ & $179,050.00$ & $179,050.00$ & $179,050.00$ & $179,050.00$ & $179,050.00$ \\
\hline Marginal result $(\mathrm{MR}=\mathrm{I}-\mathrm{VC})$ & $1,021,620.00$ & $1,432,020.00$ & $2,019,445.00$ & $2,019,445.00$ & $2,019,445.00$ \\
\hline $\begin{array}{l}\text { Break-even point } \\
(\mathrm{BEP}=(\mathrm{FC} / \mathrm{MR}) \times 100),(\text { in } \%)\end{array}$ & 17.53 & 12.50 & 8.87 & 8.87 & 8.87 \\
\hline $\begin{array}{l}\text { Break-even point by value } \\
(\mathrm{BEPv}=(\mathrm{I} \times \mathrm{BEP}) / 100)\end{array}$ & $350,521.72$ & $300,079.61$ & $265,988.92$ & $265,988.92$ & $265,988.92$ \\
\hline $\begin{array}{l}\text { Margin of safety (in \%) } \\
(\mathrm{LS}=((1-(\mathrm{BEPV} / \mathrm{I})) \times 100)\end{array}$ & 82.47 & 87.50 & 91.13 & 91.13 & 91.13 \\
\hline
\end{tabular}

Source: authors calculations according to IEP, 2016.

Break-even point of profitability shows critical and minimal values of production volume and sales revenues, below which investment in raspberry plantation, required mechanization and equipment is not profitable (Table 21.). It could be concluded, in both scenarios, that the investment is the riskiest in the first year of plantation establishment. Slightly better results in Scenario 2 are in line to fact that the plantation enters the period of full yielding after the third year of exploitation. In other words, retention of profitability requires that production volume in first year must not fall below $17.95 \%$, or $17.53 \%$ of the planned yields. Similarly realized sales revenues in same year should not be less than $358,954.31$ RSD, or 350,521.72 RSD.

The margin of safety indicates the maximum percentage of decrease in sales volume or in total yield of fruits that will not cause the loss at agricultural holding. According to indicator value, the investment has the smallest risk during the last three years of observed period, permitting the decline in production volume for $91.03 \%$, or $91.13 \%$. 
Table 22. Variable costs (in RSD)

\begin{tabular}{|l|r|r|r|r|r|r|}
\hline \multirow{2}{*}{ Element } & \multicolumn{5}{c|}{ Year of project } \\
\cline { 2 - 7 } & \multicolumn{7}{|c|}{ I } & \multicolumn{1}{c|}{ II } & \multicolumn{1}{c|}{ III } & \multicolumn{1}{c|}{ IV } & V \\
\hline \multicolumn{7}{|c|}{ Scenario 1 } \\
\hline Variable costs (VC = MC + L) & $1,002,380.00$ & $991,980.00$ & $1,004,555.00$ & $1,004,555.00$ & $1,004,555.00$ \\
\hline Material costs (MC) & $382,380.00$ & $371,980.00$ & $384,555.00$ & $384,555.00$ & $384,555.00$ \\
\hline Labor (L) & $620,000.00$ & $620,000.00$ & $620,000.00$ & $620,000.00$ & $620,000.00$ \\
\hline \multicolumn{7}{|c|}{ Scenario 2 } \\
\hline Variable costs (VC $=\mathrm{MC}+\mathrm{L})$ & $978,380.00$ & $967,980.00$ & $980,555.00$ & $980,555.00$ & $980,555.00$ \\
\hline Material costs (MC) & $358,380.00$ & $347,980.00$ & $360,555.00$ & $360,555.00$ & $360,555.00$ \\
\hline Labor $(\mathrm{L})$ & $620,000.00$ & $620,000.00$ & $620,000.00$ & $620,000.00$ & $620,000.00$ \\
\hline
\end{tabular}

Source: authors calculations according to IEP, 2016.

Table 23. Fixed costs (in RSD)

\begin{tabular}{|l|r|r|r|r|r|}
\hline \multirow{2}{*}{ Element } & \multicolumn{7}{c|}{ Year of project } \\
\cline { 2 - 7 } & I & II & III & \multicolumn{1}{c|}{ IV } & V \\
\hline \multicolumn{7}{|c|}{ Scenario 1 } \\
\hline Fixed costs (FC= IMC - L) & $179,050.00$ & $179,050.00$ & $179,050.00$ & $179,050.00$ & $179,050.00$ \\
\hline $\begin{array}{l}\text { Immaterial costs (IMC), without } \\
\text { depreciation and interest on credit }\end{array}$ & $799,050.00$ & $799,050.00$ & $799,050.00$ & $799,050.00$ & $799,050.00$ \\
\hline Labor (L) & $620,000.00$ & $620,000.00$ & $620,000.00$ & $620,000.00$ & $620,000.00$ \\
\hline & \multicolumn{7}{|c|}{ Scenario 2 } & & \\
\hline Fixed costs (FC= IMC - L) & $179,050.00$ & $179,050.00$ & $179,050.00$ & $179,050.00$ & $179,050.00$ \\
\hline $\begin{array}{l}\text { Immaterial costs (IMC), without } \\
\text { depreciation and interest on credit }\end{array}$ & $799,050.00$ & $799,050.00$ & $799,050.00$ & $799,050.00$ & $799,050.00$ \\
\hline Labor (L) & $620,000.00$ & $620,000.00$ & $620,000.00$ & $620,000.00$ & $620,000.00$ \\
\hline
\end{tabular}

Source: authors calculations according to IEP, 2016.

Consideration of variable and fixed costs in raspberry production (Table 22 and 23.) is in function of presented indicators (break-even point and margin of safety) calculation. According to total variable costs, their lower value makes Scenario 2 more favorable.

\section{Conclusion}

Results of economic analysis with focus on appropriateness of investment in raspberry plantation that includes conventional production and production with the use of renewable energy sources are based on real data, showing that investing in both observed cases (Scenario 1 and Scenario 2) is socially acceptable, economically profitable and ecologically safe.

Analyzing the justification of investment project (establishment of raspberry plantation) by the use of dynamic methods for the assessment of investment economic effectiveness, it could be seen the slight advantage of conventional production of raspberries that does not involve the use of fossil fuels. Additionally, ecological aspect gives the unconditional support to raspberry production with the use of renewable energy, throughout the application of new - clean technologies, adherence to the principles of good agricultural practice and adoption of the safe food production concept. 
All values of presented indicators could be additionally improved after the use of potential public subsidies created to support the investment in raspberry production and purchase of required mechanization and equipment.

\section{Literature}

1. Ašonja, A., Pekez, J., Janjić, N., Mikić, D. (2016): The validity for the application of solar energy in irrigation of perennial plants in fruit growing in the Republic of Serbia, Applied Engineering Letters, vol. 1, no. 3, pp. 85-90.

2. Blagojević, R., Božić, V. (2012): Tehnologija proizvodnje maline, Kancelarija za program podrške u privatnom sektoru za podršku sektoru voćarstva i bobičastog voća u Južnoj Srbiji, Niš, Srbija, p. 50, (available at: http://ntpcacak.rs/aplikacije/admin/pdf/ Tehnologija\%20proizvodnje\%20maline.pdf).

3. Chel, A., Kaushik, G. (2011): Renewable energy for sustainable agriculture, Agronomy for Sustainable Development, vol. 31, no. 1, pp. 91-118.

4. FAOSTAT (2017): Podaci o proizvodnji maline u državama vodećim proizvođačima maline, baza FAOSTAT, Rome, Italy, accessed at: 20.03.2017., (available at: www.fao. org/faostat/en/\#data/QC).

5. IEP (2015): Tehno-ekonomski aspekti primene obnovljivih izvora energije i mobilnih robotizovanih solarnih elektro-generatora u poljoprivredi, studija, IEP, IMP, PSSS Padinska Skela, Beograd, Srbija, p. 113.

6. IEP (2016): Podaci vezani za podizanje i eksploataciju zasada maline i prateće opreme, interna dokumentacija (podaci dobijeni kroz dubinski intervju sa nosiocem odabranog poljoprivrednog gazdinstva sa teritorije grada Čačka), 16. novembar 2016. godine, Institut za ekonomiku poljoprivrede, Beograd, Srbija.

7. Jovanović, D., Milenković, N., Damnjanović, R. (2017): Ocenjivanje i predviđanje potreba potrošača, Oditor, Vol. 3, No. 1, pp. 70-79.

8. Keserović, Z., Magazin, N., Kurjakov, N., Dorić, M., Gošić, J. (2014): Popis poljoprivrede 2012: Poljoprivreda u Republici Srbiji - Voćarstvo, Republički zavod za statistiku, Beograd, Srbija, p. 94.

9. Kljajić, N. (2014): Efikasnost investicija u proizvodnji maline, monografija, Institut za ekonomiku poljoprivrede, Beograd, Srbija.

10. Kljajić, N. (2016): Analysis of conditions and results of the raspberry production in Arilje raspberry-mount, thematic proceedings, Sustainable agriculture and rural development in terms of the Republic of Serbia strategic goals realization within the Danube Region development and implementation clean technologies in agriculture, IAE Belgrade, Serbia, pp. 234-253.

11. Kljajić, N., Subić, J., Sredojević, Z. (2017): Profitability of raspberry production on holdings in the territory of Arilje, Economic of Agriculture, vol. 64, no. 1, pp. 57-68.

12. Kljajić, N., Vuković, P., Arsić, S. (2013): Tendencies related to the production of raspberries in the Republic of Serbia, Economics of Agriculture, vol. 60, no. 1, pp. 39-48. 
13. Milenković, S., Kalentić, M., Stefanović, E., Milenković, A. (2011): Vodič za organsku proizvodnju maline, GIZ, Beograd, Srbija, p. 32.

14. Nastić, P. (2014): Malina, portal Agronomija, accessed at: 20.3.2017., (available at: http:// agronomija.rs/2014/malina/).

15.Paraušić, V., Simeunović, I. (2016): Market analysis of Serbia’s raspberry sector and cluster development initiatives, Economics of Agriculture, vol. 63, no. 4, pp. 1417-1431.

16. RZS (2017): Podaci o proizvodnji maline u Republici Srbiji za period 2012-2016, baza Republičkog zavoda za statistiku, Beograd, Srbija, (available at: www.stat.gov.rs/WebSite/ Public/ReportResultView.aspx?rptKey=indId $\% 3 \mathrm{~d} 130102 \mathrm{IND} 01 \% 26102 \% 3 \mathrm{dRS} \% 262 \%$ $3 \mathrm{~d} 201200 \% 2 \mathrm{c} 201300 \% 2 \mathrm{c} 201400 \% 2 \mathrm{c} 201500 \% 2 \mathrm{c} 201600 \% 2639 \% 3 \mathrm{~d} 35000 \% 266 \% 3 \mathrm{~d} 1$ $\% 2 \mathrm{c} 2 \% 2 \mathrm{c} 3 \% 26 \mathrm{sAreaId} \% 3 \mathrm{~d} 130102 \% 26 \mathrm{dType} \% 3 \mathrm{dName} \% 261$ Type $\% 3 \mathrm{dSerbianCyrillic}$, accessed at: 20.03.2017).

17. Stojanovic, Ž., Jovanovic Gavrilovic, B., Loncar, D., Jankovic, I., Ristic, B., Gligoric, M. (2014): Global and local raspberry supply chains - National level report of Serbia, Faculty of Economics, University of Belgrade, Serbia, p. 77, (available at: http://glamur. eu/wp-content/uploads/2015/04/glamur-wp3-serbia-raspberry-2-cases.pdf

18. Subić, J. (2010): Specifičnosti procesa investiranja u poljoprivredi, Institut za ekonomiku poljoprivrede, Beograd, Srbija, p. 192.

19. Trajković, S., Milanović, M. (2012): Navodnjavanje voćnjaka, Kancelarija za program podrške u privatnom sektoru za podršku sektoru voćarstva i bobičastog voća u Južnoj Srbiji, Fruits \& Berries, Niš, Srbija, p. 55, (available at: http://ntpcacak.rs/aplikacije/ admin/pdf/Navodnjavanje\%20vocnjaka.pdf).

20.UCS (2003): Renewable energy and agriculture: A natural fit, Union of concerned scientists, Cambridge, USA, accessed at: 10.6.2017., (available at: www.ucsusa.org/sites/ default/files/legacy/assets/documents/clean_energy/agfs_overview_2003.pdf).

21. Veličković, N. (2007): Malina-praktični priručnik, Pegaz, Bijelo Polje, Crna Gora, p. 65. 


\title{
PROIZVODNJA MALINE U USLOVIMA PRIMENE OBNOVLJIVE ENERGIJE ${ }^{10}$
}

\section{Jonel Subičc11, Nataša Kljajićc ${ }^{12}$, Marko Jeločnik ${ }^{13}$}

\begin{abstract}
Sažetak
Rad je tematski usmeren ka ekonomskim efektima uvođenja energije iz obnovljivih izvora (solarna energija) u proces proizvodnje maline (primarno aktivnostnavodnjavanja). Cilj rada je da se oceni ekonomska efektivnost investiranja u podizanje i eksploataciju zasada maline i implementaciju neophodne opreme i mehanizacije, pri čemu ocena obuhvata dva investiciona scenarija, prvog konvencionalnog načina zasnivanja i korišćenja malinjaka, $i$ drugog koji organizaciono uključuje i ulaganje u mobilni solarni robotizovani elektrogenerator. Metodološki, ocena ekonomskih efekata podrazumeva primenu dinamičkih metoda i metode za ocenu investicionih ulaganja u uslovima neizvesnosti (neto sadašnja vrednost, interna stopa rentabilnosti, vreme povraćaja i donja tačka rentabilnosti). Dobijeni rezultati pokazuju da, osim ekološkog benefita, ulaganja u uređaj za transfer obnovljive u električnu energiju, korišćen u procesu uzgoja maline, poseduje visoku ekonomsku opravdanost.
\end{abstract}

Ključne reči: proizvodnja maline, ocena investicija, obnovljiva energija.

10 Rad je deo istraživanja na projektu III 46006 - Održiva poljoprivreda i ruralni razvoj u funkciji ostvarivanja strateških ciljeva Republike Srbije u okviru dunavskog regiona, finansiranog od strane Ministarstva prosvete, nauke i tehnološkog razvoja Republike Srbije.

11 Vanredni profesor, dr Jonel Subić, viši naučni saradnik, Institut za ekonomiku poljoprivrede, Volgina 15, 11060 Beograd, Republika Srbija, Telefon: +381 116972 858, e-mail: jonel s@iep.bg.ac.rs

12 Dr Nataša Kljajić, naučni saradnik, Institut za ekonomiku poljoprivrede, Volgina 15, 11060 Beograd, Republika Srbija, Telefon: +381 116972 858, e-mail: natasa_k@iep.bg.ac.rs

13 Marko Jeločnik M.A., stručni saradnik, Institut za ekonomiku poljoprivrede, Volgina 15, 11060 Beograd, Republika Srbija, Telefon: +381 116972 858, e-mail: marko j@iep.bg.ac.rs

EP 2017 (64) 2 (821-843) 